\title{
Polymorphisms in DNA Repair Gene XRCC3 and Susceptibility to Breast Cancer in Saudi Females
}

\author{
Alaa Mohammed Ali, ${ }^{1}$ Huda AbdulKareem, ${ }^{2}$ Mohammad Al Anazi, \\ Narasimha Reddy Parine, ${ }^{3}$ Jilani Purusottapatnam Shaik, ${ }^{3}$ Abdullah Alamri, ${ }^{3}$ \\ Akbar Ali Khan Pathan, ${ }^{3}$ and Arjumand Warsy ${ }^{4}$

\begin{abstract}
${ }^{1}$ Department of Biochemistry, College of Science, King Saud University, Riyadh, Saudi Arabia
${ }^{3}$ Genome Research Chair, Department of Biochemistry, College of Science, King Saud University, Riyadh, Saudi Arabia

${ }^{4}$ Department of Biochemistry, Center for Science and Medical Studies for Girls, College of Science, King Saud University,
\end{abstract} \\ ${ }^{2}$ Comprehensive Cancer Center, Department of Women's Imaging, King Fahad Medical City, Riyadh, Saudi Arabia \\ P.O. Box 22452, Riyadh 11495, Saudi Arabia
}

Correspondence should be addressed to Arjumand Warsy; aswarsy@ksu.edu.sa

Received 13 September 2015; Revised 8 December 2015; Accepted 9 December 2015

Academic Editor: Janusz Blasiak

\begin{abstract}
Copyright (C) 2016 Alaa Mohammed Ali et al. This is an open access article distributed under the Creative Commons Attribution License, which permits unrestricted use, distribution, and reproduction in any medium, provided the original work is properly cited.
\end{abstract}

\begin{abstract}
We investigated three common polymorphisms (SNPs) in the XRCC3 gene (rs861539, rs1799794, and rs1799796) in 143 Saudi females suffering from breast cancer (median age $=51.4$ years) and 145 age matched normal healthy controls. DNA was extracted from whole blood and genotyping was conducted using PCR-RFLP. rs1799794 showed significant association, where AA and $\mathrm{AA}+\mathrm{AG}$ occurred at a significantly higher frequency in the cancer patients compared to the control group (OR: 28.1; 95\% CI: 3.76-21.12; $\left.\chi^{2}: 22.82 ; p<0.0001\right)$. The G allele was protective and presented with a dominant model. The genotype and allele frequencies of rs861539 C $>\mathrm{T}$ and rs1799796 A $>\mathrm{G}$ did not show a significant difference when the results in the patients and controls were compared. However, the frequency of rs1799796 differed significantly in patients with different age of diagnosis, tumor grade, and ER and HER2 status. The wild type A allele occurred at a higher frequency in the ER- and HER2- group. Our results among Saudis suggest that some variations in XRCC3 may contribute to breast cancer susceptibility. In conclusion, the results obtained during this study suggest that rs1799794 in XRCC3 shows strong association with breast cancer development in Saudi females.
\end{abstract}

\section{Introduction}

Damage induced by endogenous and exogenous factors affects the integrity and stability of DNA but is constantly and effectively corrected by the DNA repair pathways. Some serious mutations in these genes are shown to result in disorders such as Xeroderma pigmentosa; however, a wide variety of common polymorphisms are reported to be linked to mild defects in DNA repair which may predispose a person to the development of different forms of cancer [13]. Extensive studies have been conducted among different populations to identify such polymorphisms, but the results from different populations are controversial $[4,5]$. Several DNA repair pathways are functional and repair different types of damage, where the double strand breaks (DSB) are corrected by either homologous recombination repair (HRR) or nonhomologous end-joining pathways [6]. The cell's susceptibility to DNA damage and its ability to repair this damage are important for cancer induction, promotion, and progression. Among the different DNA repair genes of the HRR, the X-ray repair complementing defective repair in Chinese hamster cells 3 (XRCC3) has been the subject of considerable investigation. XRCC2 and XRCC3 genes are structurally and functionally related to RAD51 which plays an important role in homologous recombination, a process, if defective, frequently involved in cancer transformation [7].

$\mathrm{X}$-ray repair complementing defective repair in Chinese hamster cells 3 (XRCC3) is a member of the RecA/Rad51related protein family that participates in HRR, maintaining chromosome stability and participating in DNA repair. 
TABLE 1: Primers used for amplification of SNPs in XRCC3.

\begin{tabular}{|c|c|c|}
\hline SNPs in $X R C C 3$ & & rimers \\
\hline \multirow{2}{*}{ Thr241Met c.722 (rs861539) } & $\mathrm{F}$ & $5^{\prime}$-GCTGTCTCGGGGCATGGCTC-3' \\
\hline & $\mathrm{R}$ & $3^{\prime}$-TTTAGCCAGGATGCGGAAGC-5' \\
\hline \multirow{2}{*}{ c.316 (rs1799794) } & $\mathrm{F}$ & $5^{\prime}$-TGAGGCGCCTAATCAGC-3' \\
\hline & $\mathrm{R}$ & $3^{\prime}$-CGCTGCTTGACACAGTCCA- $5^{\prime}$ \\
\hline \multirow{2}{*}{ c.562-14 (rs1799796) } & $\mathrm{F}$ & $5^{\prime}$-GACACCTCTACAGAGGACG-3' \\
\hline & $\mathrm{R}$ & $3^{\prime}$-CTGTGCCTAACCATCGAGAA-5' \\
\hline
\end{tabular}

XRCC3 is one of the protein components involved in the HRR pathway and Liu et al. [8] showed that XRCC3 interacts directly with RAD51 and may cooperate with it during recombinational repair mechanisms. Several polymorphisms have been identified in this gene where some of the resulting genetic variants may alter the capacity of DNA repair mechanism and hence may be associated with increased or decreased susceptibility to tumor genesis [9]. Genetic polymorphisms in HRR genes that can lead to protein haploinsufficiency are generally associated with increased cancer risk. Though the XRCC3 gene is a highly suspected candidate gene for cancer susceptibility, several association studies on the XRCC3 polymorphisms in cancer have reported conflicting results [10].

The previous published data on the association between XRCC3 Thr241Met, A4541G, and A17893G polymorphisms and breast cancer risk remains largely controversial, and population related differences in association are reported frequently. Kuschel et al. [2] performed genetic association studies in a population-based breast cancer case-control study and analyzed polymorphisms in 7 genes involved in DNA repair. Genotype frequencies differed between cases and controls for 2 polymorphisms in the XRCC3 gene. However, most subsequent studies on Caucasians failed to confirm this association $[10,11]$, though a few studies did report that XRCC3 Thr241Met is related to an increased risk of breast cancer. Several meta-analyses using pooled data were performed and some showed a small but significant increase in cancer risk [12-15].

In Saudi Arabia, as in several other countries of the world, breast cancer is the most common cancer in females [16]. Though the incidence of breast cancer is lower than in Western countries, it ranks highest, amongst all the malignancies seen among Saudi females [16]. Interest in the molecular genetics of cancer among Saudis has gained momentum over the last few years and different DNA repair genes are the focus of several studies. With this background we initiated this case-control study on Saudi breast cancer patients and investigated three commonly reported XRCC3 polymorphisms (Thr241Met c.722 (rs861539), c.562-14 (rs1799796), and c.316 (rs1799794)) in the patients in comparison with the healthy controls.

\section{Material and Methods}

2.1. Study Population. This study was approved by the Institutional Review Board (IRB) of King Fahad Hospital (KFH).
Written informed consent was obtained from all participants. This was conducted as a case-control study involving 143 females (median age $=51.3 \pm 10$ yrs) suffering from breast cancer and 145 age matched normal healthy controls, all of Saudi Arabian ethnicity. The breast cancer patients were attending the outpatient clinics of the clinical coinvestigators (KFH) in Riyadh, Saudi Arabia, and the controls were also attending KFH for minor illnesses. They were recruited following physical examinations after diagnostic exclusion of cancer or history of cancer and cancer-related diseases. Demographic data, age at diagnosis, tumor grade and receptor status of estrogen receptor (ER), progesterone receptor (PR), and human epidermal growth factor receptor 2 (HER2) were recorded.

2.2. DNA Extraction. Approximately $3 \mathrm{~mL}$ blood samples were collected by venepuncture in ethylene diamine tetra acetic acid (EDTA) containing vacutainer tubes from all subjects enrolled in the study. DNA (genomic) was extracted from blood samples using a QIAamp DNA blood mini kit (Qiagen, Valencia, CA, USA) following the manufacturer's instructions. The extracted DNA was spectrophotometrically quantitated using NanoDrop 8000 (Thermo Scientific, USA), and purity was determined using the standard A260/A280 and A260/A230 ratios.

2.3. Genotyping. Three SNPs in XRCC3 were genotyped using PCR-RFLP. The fragment of interest was amplified with the PCR primers listed in Table 1.

For the PCR, $25 \mu \mathrm{L}$ PCR mixture was prepared and it contained $20 \mathrm{ng}$ of DNA, $10 \mathrm{pmol}$ of each primer, $0.2 \mathrm{mmol} / \mathrm{L}$ of dNTPs, $2 \mathrm{mmol} / \mathrm{L}$ of $\mathrm{MgCl}_{2}$, and $1 \mathrm{U}$ of Taq DNA polymerase. Thermal cycling conditions used during this study consisted of an initial denaturation step at $95^{\circ} \mathrm{C}$ for $10 \mathrm{~min}$ followed by 35 cycles of $95^{\circ} \mathrm{C}$ for $45 \mathrm{sec}$., $60^{\circ} \mathrm{C}$ for $50 \mathrm{sec}$., and $72^{\circ} \mathrm{C}$ for $45 \mathrm{sec}$., and a final step at $72^{\circ} \mathrm{C}$ for 10 minutes. All PCR products were subjected to electrophoresis and stored at $4^{\circ} \mathrm{C}$ until required for further analysis. The fragment size obtained using each primer set is presented in Table 2. The fragments obtained were treated with the specific restriction endonuclease, that is, FokI for rs1799794, PvuII for rs1799796, and NlaIII for rs861539. The concentrations of each enzyme used were as follows: $1 \mathrm{U}$ of the enzyme FokI with BSA $(1 \mu \mathrm{L})$ and $5 \mu \mathrm{L}$ PCR products; $0.5 \mu \mathrm{L}$ NlaIII with $0.5 \mu \mathrm{L}$ BSA and $1 \mu \mathrm{L}$ buffer 4 used with $5 \mu \mathrm{L}$ PCR product; and $0.2 \mu \mathrm{L} P v u I I$ and $1 \mu \mathrm{L}$ of buffer X 2 NEB with $5 \mu \mathrm{L}$ of the PCR product. For FokI and NlaIII, digestion conditions were as follows: incubation 
TABLE 2: The size of PCR products and fragment generated upon treatment with restriction enzyme for the three SNPs in XRCC3.

\begin{tabular}{|c|c|c|c|c|}
\hline XRCC3 SNP & $\begin{array}{c}\text { PCR } \\
\text { product size } \\
(\mathrm{bp}) \\
\end{array}$ & $\begin{array}{c}\text { RE } \\
\text { used }\end{array}$ & Genotype & $\begin{array}{c}\text { Fragment sizes (bp) after } \\
\text { RE treatment }\end{array}$ \\
\hline Thr241Met (rs861539) & 231 & NlaIII & $\mathrm{C}>\mathrm{T}$ & $\begin{array}{c}\text { CC: } 231,12 \mathrm{bp} \\
\text { CT: } 231,107,112 \& 12 \mathrm{bp} \\
\text { TT: } 112,107 \& 12 \mathrm{bp}\end{array}$ \\
\hline rs1799794 & 293 & FokI & $A>G$ & $\begin{array}{c}\text { AA: } 100 \& 193 \mathrm{bp} \\
\text { AG: } 100,193 \& 293 \mathrm{bp} \\
\text { GG: } 293 \mathrm{bp}\end{array}$ \\
\hline rs1799796 & 650 & PvuII & $A>G$ & $\begin{array}{c}\text { AA: } 650 \mathrm{bp} \\
\text { AG: } 283,367 \& 650 \mathrm{bp} \\
\text { GG: } 283 \& 376 \mathrm{bp}\end{array}$ \\
\hline
\end{tabular}

RE: restriction endonuclease; SNP: single nucleotide polymorphism; PCR: polymerase chain reaction; bp: base pair.

TABLE 3: Demographic data, tumor grade, and receptor status of the breast cancer patients, investigated during this study.

\begin{tabular}{|c|c|c|c|c|c|}
\hline & $\begin{array}{c}\text { Average } \\
\text { age (years) }\end{array}$ & $\begin{array}{c}\text { Tumor grade } \\
\text { (number of } \\
\text { patients) }\end{array}$ & $\begin{array}{l}\text { ER status } \\
\text { (number of } \\
\text { patients) }\end{array}$ & $\begin{array}{l}\text { PR status } \\
\text { (number of } \\
\text { patients) }\end{array}$ & $\begin{array}{c}\text { HER2 status } \\
\text { (number of } \\
\text { patients) }\end{array}$ \\
\hline Cancer patients & $\begin{array}{l}\text { Group 1: }<48=72 \\
\text { Group 2: }>48=71\end{array}$ & $\begin{array}{c}\mathrm{I}=18 \\
\mathrm{II}=71 \\
\mathrm{III}=45 \\
\mathrm{IV}=9\end{array}$ & $\begin{array}{l}\mathrm{ER}+=55 \\
\mathrm{ER}-=88\end{array}$ & $\begin{array}{l}\mathrm{PR}+=59 \\
\mathrm{PR}-=84\end{array}$ & $\begin{array}{l}\text { HER2 }+=71 \\
\text { HER2- }=69\end{array}$ \\
\hline
\end{tabular}

at $37^{\circ} \mathrm{C}$ for 3 hours followed by incubation at $65^{\circ} \mathrm{C}$ for $20 \mathrm{~min}$., while for PvuII, the PCR product was incubated at $37^{\circ} \mathrm{C}$ for 3 hours. After digestion, the digestion products were subjected to electrophoresis in 3\% agarose gel, and the size of the fragments obtained for each genotype is presented in Table 2.

Five percent of the samples were randomly selected and subjected to sequencing analysis as a quality control measure for verification of genotyping procedures. The results were reproducible without any discrepancies.

2.4. Statistical Analysis. Genotypes were assigned to each sample, and genotype and allelic frequencies were manually calculated and checked for deviation from the Hardy-Weinberg equilibrium (HWE) (https://ihg.gsf.de/cgi-bin/hw/hwal .pl). The control and patients obeyed HWE $(p>0.05)$. The genotype and allele frequencies in cases and controls were compared using the chi square test and odds ratios (OR), and $95 \%$ confidence intervals (CI) were calculated by Fisher's exact test (two-tailed). Patients were grouped based on the age of diagnosis (<48 and $>48$ ), tumor grade (grades I, II, III, and IV), and hormone receptor status (ER+/ER-; PR+/PR-; and HER2+/HER2-). The genotype and allele frequencies were calculated in each group and compared using SPSS 18.0 for Windows. A $p$ value of $\leq 0.05$ was considered statistically significant.

\section{Results}

The age of the female patients suffering from breast cancer ranged from 28 to 79 years and that of the normal control ranged from 28 to 68 years. The age of diagnosis varied, but the majority were diagnosed above the age of 48 years.
The ER, PR, and HER status were used to group the females as positive $(+)$ or negative $(-)$ for the receptor and the results are presented in Table 3. The tumor grade was assessed and the majority of the patients were in Grade II or III. 27 patients were triple negative and 40 were triple positive.

The frequency of the genotypes and alleles of the three SNPs was calculated in the total breast patients and control groups and the results are presented in Table 4. One of the SNPs showed association, where the genotype and allele frequencies of rs1799794 ( $\mathrm{A}>\mathrm{G}$ ) showed a significant difference when the results in the patients and controls were compared.

The genotype and allele frequencies of the three SNPs in breast cancer patients were also compared between the patients grouped on the basis of age of diagnosis, tumor grade, and ER, PR, and HER status. The genotype and allele frequencies of rs1799794 did not show any difference between the ER+/ER-, PR+/PR-, and HER+/HER- patients, patients with different tumor grades and patients with different ages of diagnosis (results not shown). Most significant differences were seen in the frequency of rs1799796 in patients with different age of diagnosis, different tumor grades, and different ER and HER 2 status. Only the results that were significantly different are presented in Table 5. Between PR+ and PR-, there were no significant differences in the genotype and allele frequency of rs1799796 (results not presented).

Of the 143 breast cancer patients, there were 27 (18.9\%) triple negative (ER-, PR-, and HER2-) patients. The genotype frequencies of the three studied SNPs were calculated in the triple negative group and compared to the results obtained in the normal control. Genotype and allele frequencies of rs861539 and rs1799796 were not different in the patients and control group; however, significant differences were seen in the frequencies of rs1799794 in the triple 
TABLE 4: Genotype and allele frequencies of studied SNPs in breast cancer patients and controls.

\begin{tabular}{|c|c|c|c|c|c|c|}
\hline & \multirow{2}{*}{$\begin{array}{c}\text { Cancer }(\text { total }=143) \\
\text { Number }(\%)\end{array}$} & \multirow{2}{*}{$\begin{array}{c}\text { Control }(\text { total }=145) \\
\text { Number }(\%)\end{array}$} & \multicolumn{3}{|c|}{ Breast cancer versus control } & \multirow{2}{*}{$p$ value } \\
\hline & & & OR & $95 \% \mathrm{CI}$ & $\chi^{2}$ & \\
\hline \multicolumn{7}{|c|}{ XRCC3 Thr241Met rs861539 C>T, genotype frequency } \\
\hline $\mathrm{CC}$ & $43(30.07)$ & $32(22.07)$ & Ref. & & & \\
\hline $\mathrm{CT}$ & $73(51.05)$ & $78(53.79)$ & 0.7 & $0.4-1.25$ & 1.41 & 0.236 \\
\hline TT & $27(18.89)$ & $35(24.14)$ & 0.59 & $0.3-1.16$ & 2.35 & 0.125 \\
\hline $\mathrm{CT}+\mathrm{TT}$ & $100(69.93)$ & $113(77.93)$ & 0.67 & $0.4-1.15$ & 2.11 & 0.146 \\
\hline $\mathrm{CT}+\mathrm{CC}$ & $116(81.11)$ & $110(75.86)$ & 1.35 & $0.8-2.39$ & 1.11 & 0.292 \\
\hline \multicolumn{7}{|c|}{ Alleles frequency } \\
\hline $\mathrm{C}$ & $159(55.59)$ & $142(48.97)$ & Ref. & & & \\
\hline $\mathrm{T}$ & $127(44.41)$ & $148(51.03)$ & 0.77 & $0.6-1.08$ & 2.29 & 0.1 \\
\hline \multicolumn{7}{|c|}{ XRCC3 rs1799794 A>G, genotype frequency } \\
\hline AA & $102(71.33)$ & $93(64.14)$ & Ref. & & & \\
\hline AG & $40(27.97)$ & $28(19.3)$ & 1.3 & $0.7-2.28$ & 0.86 & 0.353 \\
\hline GG & $1(0.007)$ & $24(16.55)$ & 0.03 & $0.005-0.28$ & 20.77 & $<0.0001$ \\
\hline $\mathrm{AG}+\mathrm{GG}$ & $41(28.67)$ & $52(35.86)$ & 0.72 & $0.44-1.18$ & 1.7 & 0.191 \\
\hline $\mathrm{AA}+\mathrm{AG}$ & $142(99.3)$ & $121(83.44)$ & 28.1 & $3.76-21.12$ & 22.82 & $<0.0001$ \\
\hline \multicolumn{7}{|c|}{ Alleles frequency } \\
\hline A & $244(85.33)$ & $214(73.74)$ & Ref. & & & \\
\hline G & $42(14.68)$ & $76(26.2)$ & 0.48 & $0.32-0.74$ & 11.73 & $<0.0001$ \\
\hline \multicolumn{7}{|c|}{ XRCC3 rs1799796 A > G, genotype frequency } \\
\hline $\mathrm{AA}$ & $59(41.26)$ & $61(42.07)$ & Ref. & & & \\
\hline AG & $53(37.06)$ & $55(37.93)$ & 0.99 & $0.59-1.67$ & 0.00 & 0.988 \\
\hline GG & $31(21.67)$ & $29(20.0)$ & 1.10 & $0.59-2.05$ & 0.10 & 0.751 \\
\hline $\mathrm{AG}+\mathrm{GG}$ & $84(58.74)$ & $84(57.9)$ & 0.9 & $0.51-1.59$ & 0.12 & 0.726 \\
\hline $\mathrm{AA}+\mathrm{AG}$ & $112(78.32)$ & $116(80.0)$ & 1.03 & $0.65-1.65$ & 0.02 & 0.889 \\
\hline \multicolumn{7}{|c|}{ Alleles frequency } \\
\hline A & $171(59.79)$ & $177(61.03)$ & Ref. & & & \\
\hline G & $115(40.21)$ & $113(38.96)$ & 1.05 & $0.75-1.47$ & 0.09 & 0.76 \\
\hline
\end{tabular}

$\mathrm{OR}=$ odds ratio; $95 \% \mathrm{CI}=95 \%$ confidence interval; $\chi^{2}=$ chi square. $\mathrm{SNP}=$ single nucleotide polymorphism; Ref.: reference.

negative cancer patients and control group. Only the results showing significant differences are presented in Table 6.

\section{Discussion}

It is well established that an individual's capacity or risk toward developing cancer can be altered by genetic variations in DNA repair genes [17]. Polymorphisms that lead to protein haploinsufficiency are associated with an increased risk of cancer development. Studies conducted over the past decade have identified such variations in a number of DNA repair genes, which are associated with either an increased susceptibility or an increased resistance to the development of cancer since they may modify DNA repair capacity. These repair genes have a pivotal role in maintaining genomic stability through different pathways and their correct functioning is important for genetic stability. Among the many genes that have been studied in recent years, $X R C C 3$ has been implicated as one of the candidates. It contributes to important DNA repair mechanisms and plays a role in the repair of double strand breaks induced by a variety of external and internal factors, including ionizing radiation, alkylating agents, and reactive oxygen species. Studies in humans and mice with XRCC3 gene disruption confirm that these responses are likely to contribute to cancer induction and/or progression [18-20]. It is emphasized that the study of such variations may help in understanding the aetiology of cancer.

Studies in several populations have shown that XRCC3 has several SNPs which exhibit polymorphism and that different populations differ significantly in the genotype and allele frequencies of these SNPs [21]. Studies conducted on different types of cancer show several contradictory results, where some studies have shown an association between some SNPs in XRCC3 and a risk of colorectal cancer, gastric cancer, breast cancer, colorectal cancer, lung cancer, glioma and meningioma, liver cancer, or head and neck cancer [3, 2229 ], while other studies have failed to show any association $[30,31]$. Sliwinski et al. [32] suggested that these polymorphisms in the XRCC3 gene might be used as a predictive factor of precancerous lesion for head and neck cancer in a Polish population. In this respect a few studies related to different polymorphisms in XRCC3 and their interaction with different cancers are listed in Table 6, which also shows several contradictory findings. 
TABLE 5: Comparison of the genotype and allele frequencies of the three SNPs in breast cancer patients, grouped on the basis of age of diagnosis, tumor grade, and ER and HER status (only results that have a statistically significant difference between the compared groups are shown).

\begin{tabular}{|c|c|c|c|c|c|c|}
\hline \multirow{2}{*}{$\begin{array}{l}\text { Grouping parameter } \\
\text { Age of diagnosis } \\
\text { rsl799796 }(A>G) \\
\text { Genotype }\end{array}$} & \multicolumn{2}{|c|}{ Group } & \multicolumn{4}{|c|}{ SNP statistics } \\
\hline & $\begin{array}{l}<48 \text { yrs } \\
\text { frequency }(\%)\end{array}$ & $\begin{array}{c}>48 \text { yrs } \\
\text { frequency }(\%)\end{array}$ & OR & $\mathrm{CI}$ & $\chi^{2}$ & $p$ value \\
\hline $\mathrm{AA}$ & 51.39 & 30.98 & 0.32 & $0.13-0.8$ & 6.05 & 0.014 \\
\hline AG & 33.33 & 40.84 & 2.03 & $0.95-4.3$ & 3.42 & 0.06 \\
\hline GG & 15.28 & 28.18 & 3.06 & $1.2-7.6$ & 6.05 & 0.013 \\
\hline A & 68.06 & 51.41 & 0.49 & $0.3-0.80$ & 8.24 & 0.005 \\
\hline G & 31.94 & 48.59 & 2.01 & & & \\
\hline $\begin{array}{l}\text { Tumour grade } \\
\text { rs1799796 }(A>G) \\
\text { Genotype }\end{array}$ & II frequency (\%) & $\begin{array}{l}\text { III frequency } \\
\qquad \%)\end{array}$ & OR & $\mathrm{CI}$ & $\chi^{2}$ & $p$ value \\
\hline $\mathrm{AA}$ & 35.71 & 56.82 & 5.66 & $1.47-21.8$ & 7.29 & 0.007 \\
\hline AG & 40.00 & 36.36 & 0.57 & $0.25-1.3$ & 1.77 & 0.18 \\
\hline GG & 24.29 & 6.82 & 0.17 & $0.05-0.68$ & 7.29 & 0.007 \\
\hline A & 55.71 & 75.00 & 2.38 & $1.32-4.29$ & 8.64 & 0.003 \\
\hline G & 44.29 & 25.00 & 0.41 & & & \\
\hline $\begin{array}{l}\text { ER status } \\
\text { rs1799796 }(A>G) \\
\text { Genotype }\end{array}$ & $\begin{array}{c}\text { ER- frequency } \\
(\%)\end{array}$ & $\begin{array}{c}\mathrm{ER}+\text { frequency } \\
(\%)\end{array}$ & OR & CI & $\chi^{2}$ & $p$ value \\
\hline $\mathrm{AA}$ & 43.75 & 36.78 & 0.36 & $0.13-0.97$ & 4.24 & 0.039 \\
\hline AG & 41.70 & 36.78 & 1.35 & $0.63-2.88$ & 0.60 & 0.44 \\
\hline GG & 14.65 & 26.44 & 2.77 & $1.03-7.45$ & 4.24 & 0.04 \\
\hline A & 64.58 & 55.17 & 0.56 & $0.34-0.94$ & 4.96 & 0.026 \\
\hline G & 35.42 & 44.83 & 1.77 & & & \\
\hline $\begin{array}{l}\text { HER status } \\
r s 1799796(A>G) \\
\text { Genotype }\end{array}$ & $\begin{array}{c}\text { HER- } \\
\text { frequency (\%) }\end{array}$ & $\begin{array}{c}\text { HER+ } \\
\text { frequency }(\%)\end{array}$ & OR & $\mathrm{CI}$ & $\chi^{2}$ & $p$ value \\
\hline $\mathrm{AA}$ & 47.89 & 33.80 & 0.29 & $0.11-0.75$ & 6.91 & 0.009 \\
\hline AG & 39.43 & 35.34 & 1.26 & $0.59-2.71$ & 0.37 & 0.541 \\
\hline GG & 12.68 & 30.88 & 3.45 & $1.3-8.8$ & 6.91 & 0.009 \\
\hline A & 67.61 & 51.47 & 0.51 & $0.31-0.83$ & 7.52 & 0.006 \\
\hline G & 32.39 & 48.53 & 1.96 & & & \\
\hline
\end{tabular}

$\mathrm{OR}=$ odds ratio $95 \% \mathrm{CI}=95 \%$ confidence interval; $\chi^{2}=$ chi square. $\mathrm{SNP}=$ single nucleotide polymorphism.

In this study on breast cancer patients and healthy controls, all the three studied SNPs exhibited polymorphism in the normal Saudi population and cancer patients. All three genotypes were identified for each SNP and the results suggested that some variations in XRCC3 may contribute to breast cancer susceptibility. Significant association was shown by rs1799794, an A to G transition in the $5^{\prime} \mathrm{UTR}$, where the mutant $\mathrm{G}$ allele was highly protective against breast cancer $\left(\mathrm{OR}=0.48 ; 95 \% \mathrm{CI}=0.32-0.74 ; \chi^{2}=11.73 ; p<0.0001\right)$. The protective effect was more obvious in the homozygotes for the $\mathrm{G}$ allele $\left(\mathrm{OR}=0.48 ; 95 \% \mathrm{CI}=0.32-0.74 ; \chi^{2}=11.73\right.$; $p<0.0001)$. This result is in agreement with several reports that have shown the $G$ allele to be protective against lung cancer and non-small-cell lung cancer in Chinese [33, 34] and esophageal and gastric cancer in Germans [35], and it was recently suggested that it may have a protective effect against late adverse effects induced by radiotherapy [36]. In a report from Jordan, the $G$ allele was shown to be associated with breast cancer [37], while no association was reported from the UK population [2].

The rs1799794 also showed a significant association with the triple negative cancer, since the $G$ allele was seen to be significantly protective while the wild type A allele was significantly predisposing to breast cancer development in patients who were triple negative. Hence, XRCC3 rs1799794 $\mathrm{AA}$ is a potential predictive marker for triple negative breast 
TABLE 6: Comparison of the genotype and allele frequencies of rs1799794 A>G in triple negative patients compared to the health control group.

\begin{tabular}{|c|c|c|c|c|c|c|}
\hline & \multirow{2}{*}{$\begin{array}{c}\text { Triple negative cancer (total }=27 \text { ) } \\
\text { Number }(\%)\end{array}$} & \multirow{2}{*}{$\begin{array}{c}\text { Control (total = 145) } \\
\text { Number }(\%)\end{array}$} & \multicolumn{3}{|c|}{ Breast cancer versus control } & \multirow{2}{*}{$p$ value } \\
\hline & & & OR & $95 \% \mathrm{CI}$ & $\chi^{2}$ & \\
\hline \multicolumn{7}{|c|}{ XRCC3 rs1799794 A>G, genotype frequency } \\
\hline AA & $7(25.92)$ & $93(64.14)$ & Ref. & & & \\
\hline AG & $16(59.26)$ & $28(19.3)$ & 0.949 & $0.35-2.58$ & 0.01 & 0.91 \\
\hline GG & $4(14.81)$ & $24(16.55)$ & 0.09 & $0.005-1.52$ & 5.21 & 0.022 \\
\hline $\mathrm{AG}+\mathrm{GG}$ & $20(74.07)$ & $52(35.86)$ & 0.511 & $0.19-1.35$ & 1.89 & 0.168 \\
\hline $\mathrm{AA}+\mathrm{AG}$ & $23(85.19)$ & $121(83.44)$ & 11.09 & $0.65-8.05$ & 5.19 & 0.022 \\
\hline \multicolumn{7}{|c|}{ Alleles frequency } \\
\hline A & $30(55.55)$ & $214(73.74)$ & Ref. & & & \\
\hline G & $24(44.44)$ & $76(26.2)$ & 0.35 & $0.15-0.855$ & 5.7 & 0.016 \\
\hline
\end{tabular}

$\mathrm{OR}=$ odds ratio; $95 \% \mathrm{CI}=95 \%$ confidence interval; $\chi^{2}=$ chi square. $\mathrm{SNP}=$ single nucleotide polymorphism.

cancer in Saudi women and further investigations in other populations are warranted for universal application in cancer detection and prediction.

We also evaluated rs1799794 as a predictive marker for early disease onset, disease severity, and association with the hormone receptor (ER, PR, and HER2) status, but no association was observed. Hence, it can be stated that rs1799794 is associated with breast cancer and triple negative breast cancer in Saudis, but not with disease onset or severity.

No association was observed between rs861539 and breast cancer in Saudis. This is a $\mathrm{C}>\mathrm{T}$ transition that results in the substitution of Thr241Met and has been implicated as a potential predictive marker for breast cancer in the Taiwanese population [38]. Among the Polish population, this SNP has been associated with cancer progression and grading. It has also been shown to play a role in increasing risk of breast cancer in the British [2] and Taiwanese population [38], colorectal cancer in Polish population [34], and breast and lung cancer in Taiwanese population [38, 39]. Several other studies and meta-analyses have confirmed an association between the XRCC3 Thr241Met polymorphism and it is suggested that this may be involved in modifying the risk of cancer [40]. Interestingly some studies show that it may have a protective effect $[4,41]$, while still others failed to show any association with lung cancer in the Danish [42], breast cancer in the Polish [3], Belgian [43], and Jordanian populations [37], and ovarian cancer in a meta-analysis including Caucasian, Asian, and African populations [44]. During our analysis, no differences were found in the frequency of this SNPs when the patients were separated into groups on the basis of the age of diagnosis, tumor grade, and receptor (ER, PR, and HER2) status. Hence, rs861539 cannot be considered as a predictive marker for breast cancer in Saudis.

Finally, rs1799796, an $\mathrm{A}>\mathrm{G}$ transition in the XRCC3, was studied and the genotypes and alleles failed to show any association with breast cancer in the Saudis. Several studies have investigated this mutation in different cancers and the results are contradictory even in patients suffering from the same type of cancer in different populations, as shown in Table 7. A study from the British population showed that rs1799796 decreases the risk of breast cancer [2] while another study from Belgium reported an increased risk associated with this SNP in BRCA1 and BRCA2 carriers [43]. More recently, a significant association with ovarian cancer was confirmed in a meta-analysis involving Caucasian, Asian, and African populations [44]. On the other hand, studies on ovarian cancer from the British population [45], lung cancer in Danish population [42], bladder and breast cancer in American population $[46,47]$, and prostate and urinary bladder cancer in Indians $[30,48]$ failed to show any association with this SNP. However, when we grouped our cancer patients on the bases of age of disease onset, tumor grade, and hormone receptor (ER, PR, and HER2) status, several interesting associations were observed. The A allele was found to predispose to breast cancer at a younger age, where the patients diagnosed at age $<48$ years had a significantly higher frequency compared to those who developed cancer at an age later than 48 years. The A allele also occurred at a significantly higher frequency in patients suffering from tumor grade III compared to tumor grade II, suggesting its involvement in disease severity. It also occurred at a significantly higher frequency in ER- and HER2- females compared to their ER+ and HER2+ counterparts. Hence, we suggest that rs1799796 may be considered as a disease severity marker.

In conclusion, it is obvious that populations differ in the genotype and allele frequencies of different SNPs and also differ in the extent and nature of association of a genotype or allele with disease development. Association studies play an important role in identification of genetic markers that may help in presymptomatic diagnosis of a disease state, including cancer. In addition, therapeutic measure may be directed towards those SNPs that influence gene expression of the respected gene. One drawback of such studies is that the frequencies of the SNP alleles show significant differences between different populations, even in the control groups, hence making it mandatory that studies of this nature need to be performed for each individual population, in an attempt to identify "population specific markers." In addition, such studies will contribute towards the development of the field of "personalized medicine," with individualized treatment strategies. 
TABLE 7: Association studies of rs1799794 (A/G), rs861539 (C/T), and rs1799796 (A/G) in XRCC3 in different types of cancer and in different populations.

\begin{tabular}{|c|c|c|c|c|}
\hline Cancer types & Effect & Number & Population & Ref. \\
\hline \multicolumn{5}{|c|}{ rs1799794 (A/G), association of G allele } \\
\hline Breast cancer & Protective & 143 & Saudis & * \\
\hline Esophageal and gastric & Survival & 258 & Germans & {$[35]$} \\
\hline Lung cancer & Decreased risk in carriers of $\mathrm{G}$ allele & - & Chinese & {$[33]$} \\
\hline Breast cancer risk & Modified in patients carrying BRCA1, BRCA 2 mutation & - & Belgian & {$[43]$} \\
\hline Prostate cancer & Gastrointestinal toxicity & 698 & Spanish & [49] \\
\hline Non-small-cell lung & Protective effect of $\mathrm{G}$ allele & 507 & Chinese & {$[34]$} \\
\hline Breast cancer & No association & & British & {$[2]$} \\
\hline Ovarian cancer & Association & - & Meta-analysis & {$[44]$} \\
\hline Breast cancer & Association & - & Jordanian & {$[37]$} \\
\hline \multicolumn{5}{|c|}{$r s 861539(\mathrm{C} / \mathrm{T})$, association of $\mathrm{T}$ allele } \\
\hline Breast cancer & No association & 143 & Saudis & * \\
\hline Colorectal cancer & Increased risk (association) & 100 & Polish & {$[34]$} \\
\hline Breast cancer & Increased risk (association) & 1826 & British & {$[2]$} \\
\hline Bladder cancer & Protective role & 214 & Italian & {$[41]$} \\
\hline Colorectal cancer & Protective role & 128 & British & {$[4]$} \\
\hline Lung cancer & No association & 272 & Danish & {$[42]$} \\
\hline Breast cancer & No association. Association with cancer progression and grading & 700 & Polish & {$[3]$} \\
\hline Breast cancer & Association & & Taiwanese & {$[38]$} \\
\hline Breast cancer & No association & & Jordanian & {$[37]$} \\
\hline \multicolumn{5}{|c|}{ rs1799796 (A/G), association of G allele } \\
\hline Breast cancer & No association & 143 & Saudi & * \\
\hline Bladder cancer & No association & 696 & American & {$[46]$} \\
\hline Oral premalignant lesions & Strong association (increases risk) & 147 & American & {$[50]$} \\
\hline Prostate cancer & No association & 192 & Indian & {$[48]$} \\
\hline Urinary bladder cancer & No association & 211 & Indian & {$[30]$} \\
\hline Breast cancer & Increases risk in BRCA1, BRCA2 & - & Belgian & {$[43]$} \\
\hline Breast cancer & Decreased risk & 2205 & British & {$[2]$} \\
\hline Breast cancer & No association & 1004 & American & {$[47]$} \\
\hline Lung cancer & No association & 265 & Danish & {$[42]$} \\
\hline Ovarian cancer & No association & 1600 & British & {$[45]$} \\
\hline Ovarian cancer & Association & & Meta-analysis & {$[44]$} \\
\hline
\end{tabular}

$*$ = this study.

\section{Conflict of Interests}

The authors declare that they do not have any competing interests with any group.

\section{Acknowledgment}

This project was financially supported by King Saud University, Vice Deanship of Research Chairs.

\section{References}

[1] E. Synowiec, J. Stefanska, Z. Morawiec, J. Blasiak, and K. Wozniak, "Association between DNA damage, DNA repair genes variability and clinical characteristics in breast cancer patients," Mutation Research: Fundamental and Molecular Mechanisms of Mutagenesis, vol. 648, no. 1-2, pp. 65-72, 2008.
[2] B. Kuschel, A. Auranen, S. McBride et al., "Variants in DNA double-strand break repair genes and breast cancer susceptibility," Search Results Human Molecular Genetics, vol. 11, no. 12, pp. 1399-1407, 2002.

[3] H. Romanowicz-Makowska, B. Smolarz, M. Zadrozny et al., "Single nucleotide polymorphisms in the homologous recombination repair genes and breast cancer risk in Polish women," The Tohoku Journal of Experimental Medicine, vol. 224, no. 3, pp. 201-208, 2011.

[4] R. Mort, L. Mo, C. McEwan, and D. W. Melton, "Lack of involvement of nucleotide excision repair gene polymorphisms in colorectal cancer," British Journal of Cancer, vol. 89, no. 2, pp. 333-337, 2003.

[5] X.-F. He, W. Wei, J. Su et al., "Association between the XRCC3 polymorphisms and breast cancer risk: meta-analysis based on case-control studies," Molecular Biology Reports, vol. 39, no. 5, pp. 5125-5134, 2012. 
[6] R. B. Setlow, "DNA repair pathways," in DNA Repair and Mutagenesis in Eukaryotes, W. M. Generoso, M. D. Shalby, and F. J. de Serresi, Eds., vol. 15 of Basic Life Sciences, chapter 3, pp. 45-54, Plenum Press, New York, NY, USA, 1980.

[7] C. Richardson, "RAD51, genomic stability, and tumorigenesis," Cancer Letters, vol. 218, no. 2, pp. 127-139, 2005.

[8] N. Liu, J. E. Lamerdin, R. S. Tebbs et al., "XRCC2 and XRCC3, new human Rad51-family members, promote chromosome stability and protect against DNA cross-links and other damages," Molecular Cell, vol. 1, no. 6, pp. 783-793, 1998.

[9] M. García-Closas, K. M. Egan, P. A. Newcomb et al., "Polymorphisms in DNA double-strand break repair genes and risk of breast cancer: two population-based studies in USA and Poland, and meta-analyses," Human Genetics, vol. 119, no. 4, pp. 376$388,2006$.

[10] N. R. Jacobsen, B. A. Nexø, A. Olsen et al., "No association between the DNA repair gene XRCC3 T241M polymorphism and risk of skin cancer and breast cancer," Cancer Epidemiology Biomarkers and Prevention, vol. 12, no. 6, pp. 584-585, 2003.

[11] B. Thyagarajan, K. E. Anderson, A. R. Folsom et al., "No association between XRCC1 and XRCC3 gene polymorphisms and breast cancer risk: Iowa Women's Health study," Cancer Detection and Prevention, vol. 30, no. 4, pp. 313-321, 2006.

[12] S.-A. Lee, K.-M. Lee, S. K. Park et al., "Genetic polymorphism of XRCC3 Thr241Met and breast cancer risk: case-control study in Korean women and meta-analysis of 12 studies," Breast Cancer Research and Treatment, vol. 103, no. 1, pp. 71-76, 2007.

[13] S. Han, H.-T. Zhang, Z. Wang et al., "DNA repair gene XRCC3 polymorphisms and cancer risk: a meta-analysis of 48 casecontrol studies," European Journal of Human Genetics, vol. 14, no. 10, pp. 1136-1144, 2006.

[14] M. Manuguerra, F. Saletta, M. R. Karagas et al., "XRCC3 and XPD/ERCC2 single nucleotide polymorphisms and the risk of cancer: a HuGE review," American Journal of Epidemiology, vol. 164, no. 4, pp. 297-302, 2006.

[15] K. P. Economopoulos and T. N. Sergentanis, "XRCC3 Thr241Met polymorphism and breast cancer risk: a metaanalysis," Breast Cancer Research and Treatment, vol. 121, no. 2, pp. 439-443, 2010.

[16] National Cancer Registry, Cancer Incidence Report Saudi Arabia 2002, National Cancer Registry, Riyadh, Saudi Arabia, 2007.

[17] J. Han, C. Haiman, T. Niu et al., "Genetic variation in DNA repair pathway genes and premenopausal breast cancer risk," Breast Cancer Research and Treatment, vol. 115, no. 3, pp. 613622, 2009.

[18] M. Z. Zdzienicka, "Mammalian mutants defective in the response to ionizing radiation-induced DNA damage," Mutation Research/DNA Repair, vol. 336, no. 3, pp. 203-213, 1995.

[19] M. Z. Zdzienicka, "Mammalian X-ray-sensitive mutants which are defective in non-homologous (illegitimate) DNA doublestrand break repair," Biochimie, vol. 81, no. 1-2, pp. 107-116, 1999.

[20] J. Thacker and M. Z. Zdzienicka, "The XRCC genes: expanding roles in DNA double-strand break repair," DNA Repair, vol. 3, no. 8-9, pp. 1081-1090, 2004.

[21] M. Alanazi, A. A. K. Pathan, S. A. Ajaj et al., "Dna repair genes XRCC1, XRCC3, XPD, AND OGG1 polymorphisms among the central region population of Saudi Arabia," Biological Research, vol. 46, no. 2, pp. 161-167, 2013.

[22] B. Smolarz, M. Makowska, D. Samulak et al., "Association between single nucleotide polymorphisms (SNPs) of XRCC2 and XRCC3 homologous recombination repair genes and triplenegative breast cancer in Polish women," Clinical and Experimental Medicine, vol. 15, no. 2, pp. 151-157, 2014.

[23] İ. Gök, M. Baday, S. Çetinkünar, K. Kiliç, and B. Ç. Bilgin, "Polymorphisms in DNA repair genes XRCC2 and XRCC3 risk of gastric cancer in Turkey," Bosnian Journal of Basic Medical Sciences, vol. 14, no. 4, pp. 214-218, 2014.

[24] K.-Q. Luo, S.-Q. Mu, Z.-X. Wu, Y.-N. Shi, and J.-C. Peng, "Polymorphisms in DNA repair genes and risk of glioma and meningioma," Asian Pacific Journal of Cancer Prevention, vol. 14, no. 1, pp. 449-452, 2013.

[25] S. Nissar, A. S. Sameer, T. A. Lone, N. A. Chowdri, and R. Rasool, "XRCC3 Thr241Met gene polymorphism and risk of colorectal cancer in Kashmir: a case control study," Asian Pacific Journal of Cancer Prevention, vol. 15, no. 22, pp. 9621-9625, 2014.

[26] S. Guo, X. Li, M. Gao, Y. Li, B. Song, and W. Niu, "The relationship between XRCC1 and XRCC3 gene polymorphisms and lung cancer risk in northeastern Chinese," PLoS ONE, vol. 8, no. 2, Article ID e56213, 2013.

[27] B. Mucha, K. Przybylowska-Sygut, A. J. Dziki, L. Dziki, A. Sygut, and I. Majsterek, "Association of THR241MET polymorphism of XRCC3 gene with risk of colorectal cancer in the polish population," Polish Journal of Pathology, vol. 64, no. 3, pp. 185190, 2013.

[28] R. Krupa, J. Kasznicki, M. Gajęcka et al., "Polymorphisms of the DNA repair genes XRCC1 and ERCC4 are not associated with smoking- and drinking-dependent larynx cancer in a Polish population," Experimental Oncology, vol. 33, no. 1, pp. 55-56, 2011.

[29] L. Zhang, Z. Zhang, and W. Yan, "Single nucleotide polymorphisms for DNA repair genes in breast cancer patients," Clinica Chimica Acta, vol. 359, no. 1-2, pp. 150-155, 2005.

[30] R. D. Mittal, R. Gangwar, R. K. Mandal, P. Srivastava, and D. K. Ahirwar, "Gene variants of XRCC4 and XRCC3 and their association with risk for urothelial bladder cancer," Molecular Biology Reports, vol. 39, no. 2, pp. 1667-1675, 2012.

[31] P. Ding, Y. Yang, L. Cheng et al., "The relationship between seven common polymorphisms from five DNA repair genes and the risk for breast cancer in Northern Chinese women," PLoS ONE, vol. 9, no. 3, Article ID e92083, 2014.

[32] T. Sliwinski, A. Walczak, K. Przybylowska et al., "Polymorphisms of the XRCC3 C722T and the RAD51 G135C genes and the risk of head and neck cancer in a Polish population," Experimental and Molecular Pathology, vol. 89, no. 3, pp. 358366, 2010.

[33] M. Huang, X. Chen, Y. Qiu, L. Fan, J. Chen, and L. Cai, "Relationship between XRCC3 gene polymorphisms and lung cancer," Wei Sheng Yan Jiu, vol. 40, no. 2, pp. 187-190, 2011.

[34] F. He, S.-C. Chang, G. M. Wallar, Z.-F. Zhang, and L. Cai, "Association of XRCC3 and XRCC4 gene polymorphisms, family history of cancer and tobacco smoking with non-smallcell lung cancer in a Chinese population: a case-control study," Journal of Human Genetics, vol. 58, no. 10, pp. 679-685, 2013.

[35] K. Ott, P. S. Rachakonda, B. Panzram et al., "DNA repair gene and MTHFR gene polymorphisms as prognostic markers in locally advanced adenocarcinoma of the esophagus or stomach treated with cisplatin and 5-fluorouracil-based neoadjuvant chemotherapy," Annals of Surgical Oncology, vol. 18, no. 9, pp. 2688-2698, 2011.

[36] Y.-Z. Song, F.-J. Han, M. Liu, C.-C. Xia, W.-Y. Shi, and L.-H. Dong, "Association between single nucleotide polymorphisms 
in XRCC3 and radiation-induced adverse effects on normal tissue: a meta-analysis," PLoS ONE, vol. 10, no. 6, Article ID e0130388, 2015.

[37] M. S. Al Zoubi, "X-ray repair cross-complementing protein 1 and 3 polymorphisms and susceptibility of breast cancer in a Jordanian population," Saudi Medical Journal, vol. 36, no. 10, pp. 1163-1167, 2015.

[38] C. H. Su, W. S. Chang, P. S. Hu et al., "Contribution of DNA double-strand break repair gene XRCC3 genotypes to triplenegative breast cancer risk," Cancer Genomics Proteomics, vol. 12, no. 6, pp. 359-367, 2015.

[39] H. J. Chen, W. S. Chang, T. C. Hsia et al., "Contribution of genotype of DNA double-strand break repair gene XRCC3, gender, and smoking behavior to lung cancer risk in Taiwan," Anticancer Research, vol. 35, no. 7, pp. 3893-3899, 2015.

[40] Z. Wang and W. Zhang, "Association between XRCC3 Thr241Met polymorphism and colorectal cancer risk," Tumor Biology, vol. 34, no. 3, pp. 1421-1429, 2013.

[41] M. Shen, R. J. Hung, P. Brennan et al., "Polymorphisms of the DNA repair genes XRCC1, XRCC3, XPD, interaction with environmental exposures, and bladder cancer risk in a case-control study in northern Italy," Cancer Epidemiology Biomarkers and Prevention, vol. 12, no. 11, part 1, pp. 1234-1240, 2003.

[42] N. R. Jacobsen, O. Raaschou-Nielsen, B. Nexø et al., "XRCC3 Polymorphisms and risk of lung cancer," Cancer Letters, vol. 213, no. 1, pp. 67-72, 2004.

[43] A. Vral, P. Willems, K. Claes et al., "Combined effect of polymorphisms in Rad51 and XRCC3 on breast cancer risk and chromosomal radiosensitivity," Molecular Medicine Reports, vol. 4, no. 5, pp. 901-912, 2011.

[44] C. Yuan, X. Liu, S. Yan, C. Wang, and B. Kong, "Analyzing association of the XRCC3 gene polymorphism with ovarian cancer risk," BioMed Research International, vol. 2014, Article ID 648137, 9 pages, 2014.

[45] A. Auranen, H. Song, C. Waterfall et al., "Polymorphisms in DNA repair genes and epithelial ovarian cancer risk," International Journal of Cancer, vol. 117, no. 4, pp. 611-618, 2005.

[46] X. Wu, J. Gu, H. B. Grossman et al., "Bladder cancer predisposition: a multigenic approach to DNA-repair and cell-cyclecontrol genes," American Journal of Human Genetics, vol. 78, no. 3, pp. 464-479, 2006.

[47] J. Han, S. E. Hankinson, H. Ranu, I. De Vivo, and D. J. Hunter, "Polymorphisms in DNA double-strand break repair genes and breast cancer risk in the Nurses' Health study," Carcinogenesis, vol. 25, no. 2, pp. 189-195, 2004.

[48] R. K. Mandal, R. Kapoor, and R. D. Mittal, "Polymorphic variants of DNA repair gene XRCC3 and XRCC7 and risk of prostate cancer: a study from North Indian population," DNA and Cell Biology, vol. 29, no. 11, pp. 669-674, 2010.

[49] L. Fachal, A. Gómez-Caamaño, P. Peleteiro et al., "Association of a XRCC3 polymorphism and rectum mean dose with the risk of acute radio-induced gastrointestinal toxicity in prostate cancer patients," Radiotherapy and Oncology, vol. 105, no. 3, pp. 321328, 2012.

[50] H. Yang, S. M. Lippman, M. Huang et al., "Genetic polymorphisms in double-strand break DNA repair genes associated with risk of oral premalignant lesions," European Journal of Cancer, vol. 44, no. 11, pp. 1603-1611, 2008. 

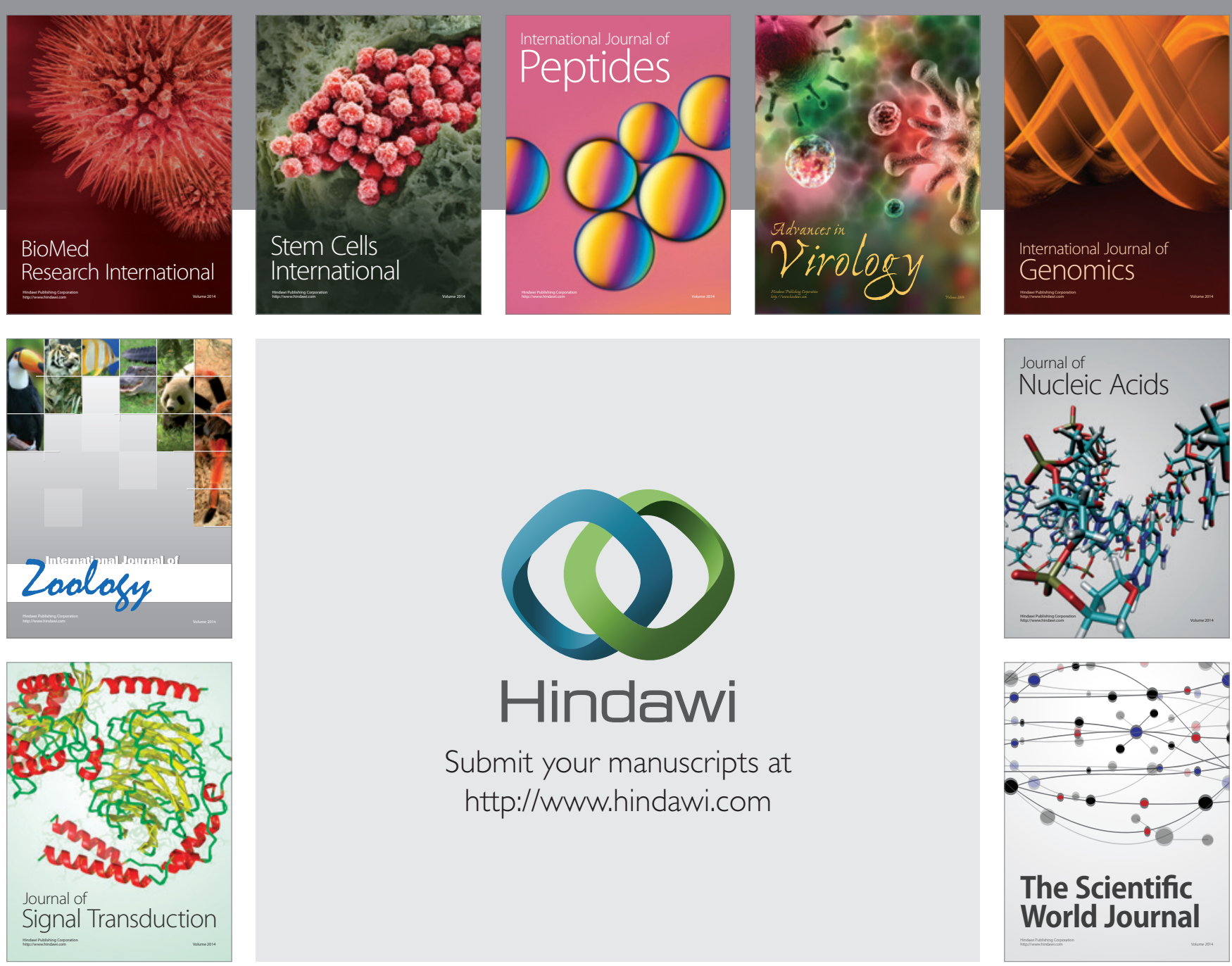

Submit your manuscripts at

http://www.hindawi.com
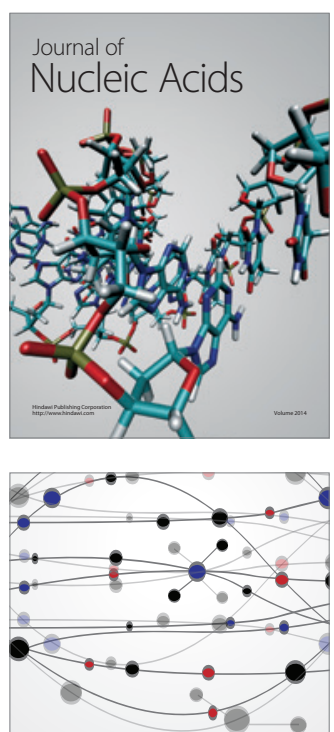

The Scientific World Journal
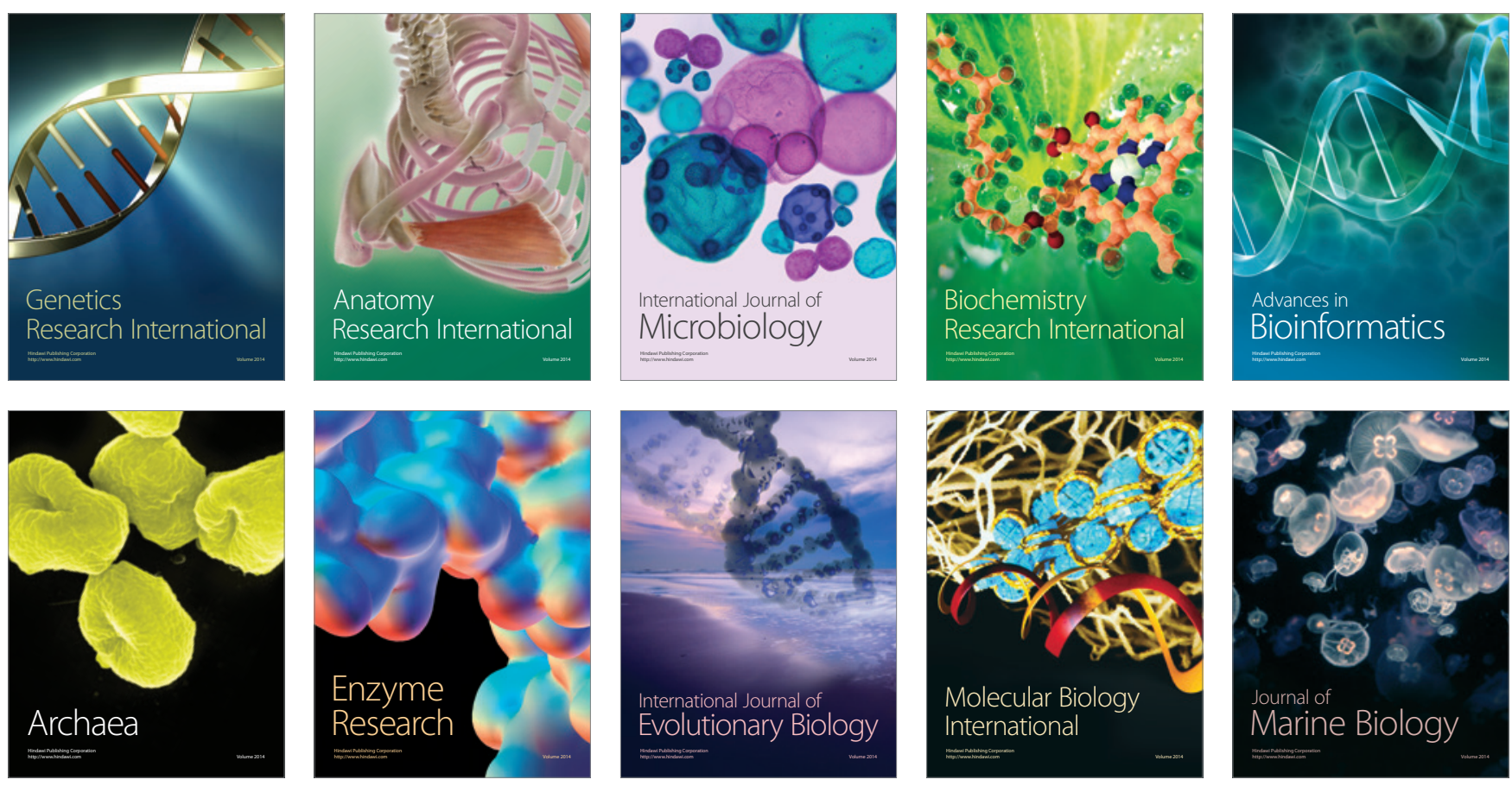